\title{
Multispectral Landsat Images of Antarctica
}

\section{U.S. GEOLOGICAL SURVEY BULLETIN 1696}

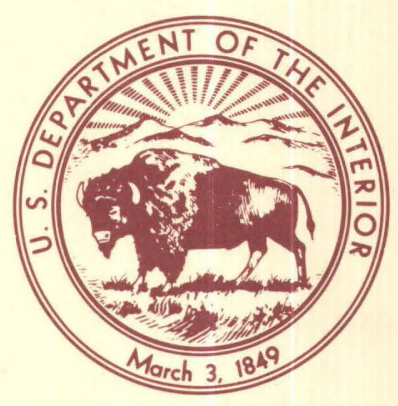




\section{Multispectral Landsat Images of Antarctica}

BY BAERBEL K. LUCCHITTA, JO-ANN BOWELL, KATHLEEN L. EDWARDS, ERIC M. ELIASON, and HOLLY M. FERGUSON 


\title{
DEPARTMENT OF THE INTERIOR \\ DONALD PAUL HODEL, Secretary
}

\author{
U.S. GEOLOGICAL SURVEY
}

Dallas L. Peck, Director

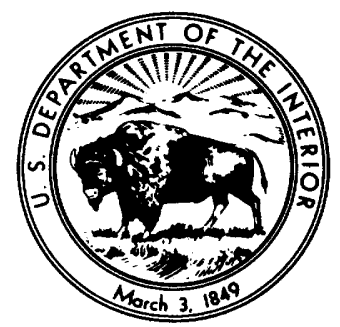

For sale by the

Books and Open-File Reports Section

U.S. Geological Survey

Federal Center, Box 25425

Denver, CO 80225

Library of Congress Cataloging-in-Publication Data

Multispectral Landsat images of Antarctica.

U.S. Geological Survey Bulletin 1696

Bibliography

Supt. of Docs. No.: I 19.3:1696

1. Earth sciences-Antarctic regions. 2. Geological mapping-Antarctic regions. 3. Antarctic regionsPhotographs from space. 4. Landsat satellites. I. Lucchitta, Baerbel K. II. Series.

QE75.B9 No. 1696

$557.3 \mathrm{~s}$

$86-600365$

[QE350]

[559.8'9] 


\title{
CONTENTS
}

\author{
Abstract 1 \\ Introduction 1 \\ Data acquisition $\mathbf{1}$ \\ Historical perspective 2 \\ Digital-image-processing methods 3 \\ Special-purpose images $\mathbf{8}$ \\ Antarctic meteorites $\mathbf{8}$ \\ Glaciological contributions 12 \\ Coastline changes 12 \\ Spectral and structural studies $\mathbf{1 7}$ \\ Conclusions 17 \\ References $\mathbf{2 0}$
}

\section{FIGURES}

1. Index map of scenes covered by Landsat computer tapes of Antarctica 2

2. Saturated and saturation-corrected composites of English Coast area 4

3. Unenhanced print and digitally enhanced composite of Queen Maud Land 6

4. False-color multispectral digital mosaic of McMurdo Sound region 9

5. Special-purpose images of Byrd Glacier region $\mathbf{1 0}$

6. False-color multispectral-image map of Convoy Range quadrangle $\mathbf{1 3}$

7. Image showing glaciological features on Ronne Ice Shelf $\mathbf{1 4}$

8. Image showing morphological features in Ellsworth Mountains and on Rutford Ice Stream 15

9. Image showing morphological features in Theron Mountains and on Slessor Glacier 16

10. Enhanced image of Byrd Glacier region $\mathbf{1 8}$

11. False-color, sinusoidally stretched image of McMurdo Sound region and Dry Valleys 19

\section{TABLE}

1. Geographic location of features mentioned in report 3 


\title{
Multispectral Landsat Images of Antarctica
}

\author{
By Baerbel K. Lucchitta, Jo-Ann Bowell, Kathleen L. Edwards, Eric M. Eliason, \\ and Holly M. Ferguson
}

\begin{abstract}
The U.S. Geological Survey has initiated a program to map Antarctica by using colored, digitally enhanced Landsat multispectral scanner (MSS) images to increase existing map coverage and to improve upon previously published Landsat maps. After overcoming several difficulties, particularly those associated with severe saturation of bright, snow-covered scenes in spectral bands 4 and 5, we compiled a mosaic image in map projection of the McMurdo Sound region. This digitally enhanced mosaic covers four complete and two partial 1:250,000-scale topographic quadrangles and shows significantly more detail in rock and ice than do previously compiled black-and-white paperprint mosaics of the region.
\end{abstract}

Digitally processed Landsat images can provide accurate and detailed base maps, and they may aid in solving several Ant arctic research problems. Some of these problems are addressed in our mapping program; results are given in this report. We prepared thematic images showing either bedrock or ice features only; maps from such images will be helpful in locating ice or rock in remote areas that are difficult to reach on the ground. Images and maps derived from them can show blue-ice areas that are easily recognized by their distinctive blue color and are important for the collection of meteorites. Furthermore, the images show--more clearly than previous images--ice rises, flow lines on ice streams and ice shelves, and buried mount ain ranges. The images also reveal that the Byrd Glacier has moved at an average velocity of 800 meters/year within 10 years; monitoring such changes in glaciers, ice shelves, and the coastline is useful in prediction of climatic changes and possible worldwide changes in sea level. We found that the resolution of Landsat MSS (about $80 \mathrm{~m}$ ) is insufficient for most detailed spectral studies because almost all rock outcrops in Antarctica are small, but we anticipate that the resolution of thematic mapper (TM) images (about $30 \mathrm{~m}$ ) will be adequate for such studies in the future.

\section{INTRODUCTION}

Antarctica is the only continent on Earth whose physiography and geology remain poorly known. It contains vast areas that are not yet shown on maps. Therefore, the U.S. Geological Survey (USGS) has begun a program to prepare digitally enhanced imagemosaic maps in color from multispectral scanner (MSS) Landsat images. In addition to increasing map coverage of Antarctica and improving existing maps, the image mosaics may enable the following: (1) superposition and correlation of different types of digital cartographic data; (2) production of specialpurpose images showing only selected features; (3) location and delineation of blue-ice areas, where meteorites are collected; (4) provision of synoptic views that aid in the detection and interpretation of glaciological features associated with ice sheets, outlet glaciers, ice streams, and ice shelves; (5) monitoring of changes in coastlines and glacial features; and (6) supplying spectral and structural information in areas of limited bedrock outcrop to aid in regional geological interpretation.

During the course of the project, we have overcome a number of technical problems, approached several of our goals, and assembled a set of spectacular images and image mosaics. This report summarizes our initial results and illustrates what can be achieved with multispectral imaging techniques in Antarctica.

\section{DATA ACQUISITION}

About 170 computer tapes containing digital Landsat images have been acquired of the coastal and near-coastal areas of Victoria Land, Marie Byrd Land, and the Antarctic Peninsula and of selected areas in the Ellsworth Mountains, the Shackleton Range, Queen Maud Land, and the Lambert Glacier-Amery Ice Shelf region (fig. 1). (Locations of named features in this report are given in table 1.) These areas were chosen because their Landsat images accurately portray 


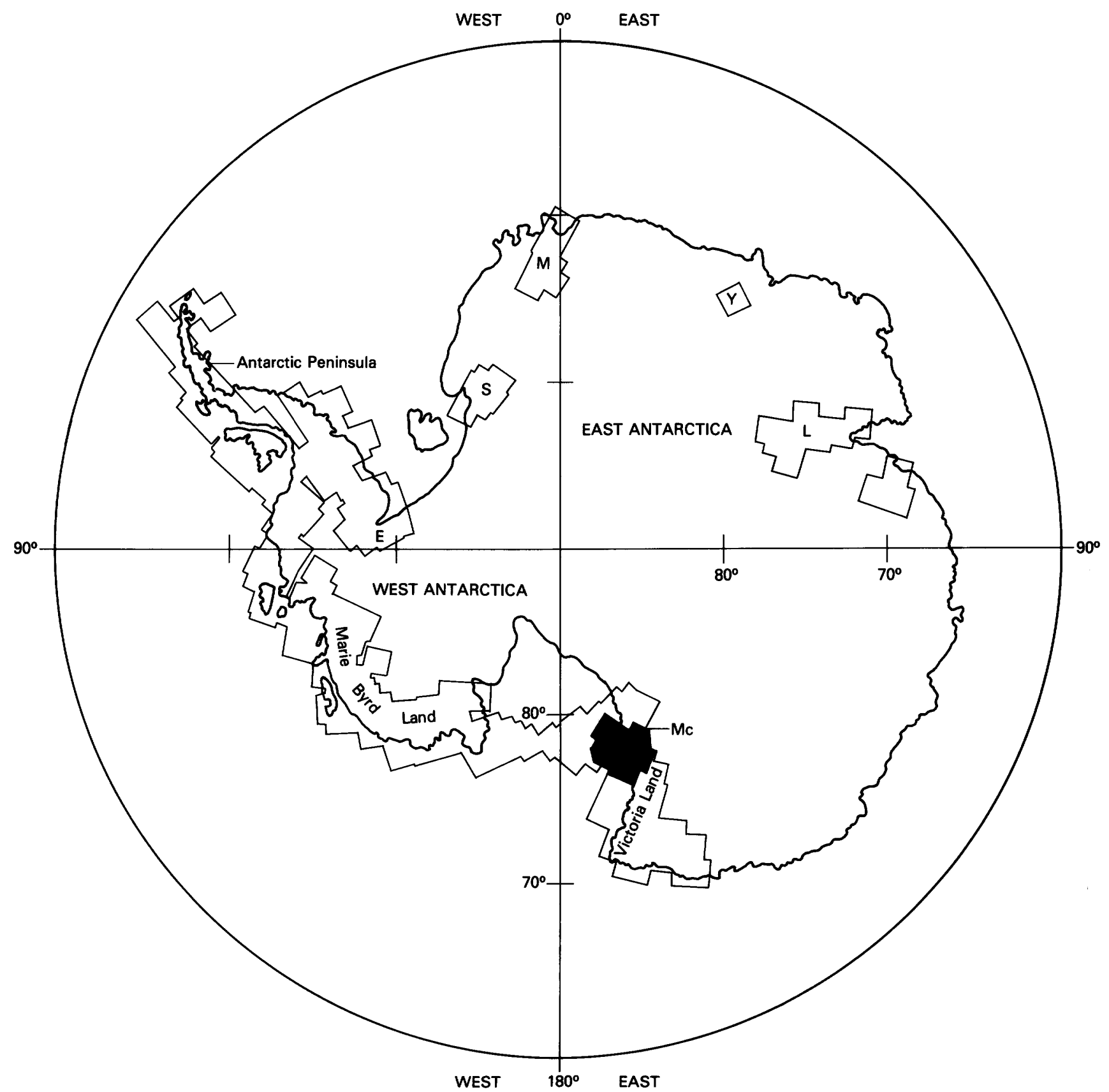

Figure 1. Index map of Antarctic scenes covered by Landsat computer tapes acquired by U.S. Geological Survey for this study. Boundary of continent shown by heavy line. E, Ellsworth Mountains; S, Shackleton Range; M, Queen Maud Land; Y, Yama to Mountains; L, Lambert Glacier-Amery Ice Shelf. Area of Mc Murdo region mosaic (Mc), solid black.

mountain ranges, nunataks, and the coastline (as recognized in the early to mid-1970's). Landsat coverage extends only to about lat $81^{\circ} \mathrm{S}$.; therefore, images of large parts of the Transantarctic Mountains are not available for analysis. Nevertheless, 79 percent of Antarctica lies north of lat $81^{\circ} \mathrm{S}$., and 55 percent of the continent is already covered by excellent or good images (having less than 10 percent clouds) (Williams and others, 1982, 1984).

\section{HISTORICAL PERSPECTIVE}

Most Landsat images of Antarctica were acquired in the early to mid-1970's during a National Aeronautics and Space Administration (NASA)-funded Earth Resources Technology Satellite (ERTS-1) investigation under the leadership of the late William R. MacDonald (Southard and MacDonald, 1974). MacDonald pioneered the use of Landsat images to 
Table 1. Geographic location of features mentioned in report

Feature

Location (central coordinates are given for large features)

\section{Allan Hills}

Amery Ice Shelf

Antarctic Peninsula

Belgica Mountains

Byrd Glacier

Dry Valleys

East Antarctica

Ellsworth Mountains

English Coast

Erebus Glacier Tongue

Ferrar Glacier

Fletcher Ice Rise

Fowler Ice Rise

Hather ton Glacier

Jutulstraumen Glacier

Kershaw Ice Rumples

Korff Ice Rise

Lake Vanda

Lambert Glacier

Marie Byrd Land

McMurdo Sound

Mount Erebus

Mulock Glacier

Pine Island Glacier

Queen Maud Land

Ronne Ice Shelf

Ross Island

Ross Ice Shelf

Rutford Ice Stream

Sentinel Range

Shackleton Range

Slessor Glacier

Spaatz Island

Theron Mountains

Transantarctic Mountains

Victoria Land

West Antarctica

Wilkes Land

Yamato Mountains $76^{\circ} 43^{\prime}$ S., $159^{\circ} 40$ ' E.

$69^{\circ} 45^{\prime}$ ' S., $71^{\circ} 00^{\prime} \mathrm{E}$.

$69^{\circ} 30^{\prime}$ ' S., $65^{\circ} 00$ ' w.

$72^{\circ} 35^{\prime}$ S., $31^{\circ} 15^{\prime}$ E.

$80^{\circ} 20^{\prime}$ ' S., $159^{\circ} 00$ ' E.

$78^{\circ} 00^{\prime}$ S., $161^{\circ} 00^{\prime} \mathrm{E}$.

$80^{\circ} 00^{\prime}$ ' S., $80^{\circ} 00$ ' E.

$78^{\circ} 45^{\prime}$ ' S., $85^{\circ} 00^{\prime}$ W.

$73^{\circ} 30^{\prime}$ ' S., $73^{\circ} 00^{\prime}$ ' w.

$77^{\circ} 42^{\prime}$ ' S., $166^{\circ} 40^{\prime}$ E.

$77^{\circ} 46$ ' S., $163^{\circ} 00$ ' E.

$78^{\circ} 20^{\prime}$ ' s., $81^{\circ} 00^{\prime}$ w.

$77^{\circ} 30^{\prime}$ ' S., $78^{\circ} 00^{\prime} \mathrm{W}$.

$79^{\circ} 55^{\prime}$ S., $157^{\circ} 35^{\prime}$. E.

$71^{\circ} 35$ ' S., $\quad 0^{\circ} 30^{\prime} \mathrm{w}$.

$78^{\circ} 45^{\prime}$ S., $75^{\circ} 40^{\prime} \mathrm{W}$.

$79^{\circ} 00^{\prime}$ S., $69^{\circ} 30^{\prime} \mathrm{W}$.

$77^{\circ} 32$ ' S., $161^{\mathrm{O}_{33}}$ ' E.

$71^{\circ} 00^{\prime}$ S., $70^{\circ} 00^{\prime} \mathrm{E}$.

$80^{\circ} 00^{\prime}$ 'S., $120^{\circ} 00^{\prime}$ w.

$77^{\circ} 30$ ' S., $165^{\circ} 00$ ' E.

$77^{\circ} 32$ ' S., $167^{\circ} 10^{\prime} \mathrm{E}$.

$79^{\circ} 00^{\prime}$ S., $160^{\circ} 00$ ' E.

$75^{\circ} 10^{\prime}$ S., $100^{\circ} 00^{\prime} \mathrm{W}$.

$72^{\circ} 30^{\prime}$ S., $12^{\circ} 00$ ' E.

$78^{\mathrm{O}_{30}}$ ' S., $61^{\circ} 00^{\prime} \mathrm{w}$.

$77^{\circ} 30$ ' S., $168^{\circ} 00$ ' E.

$81^{\mathrm{O}_{30}}$ ' S., $175^{\circ} 00^{\prime} \mathrm{W}$.

$79^{\circ} 00^{\prime}$ S., $81^{\circ} 00$ ' W.

$78^{\circ} 10^{\prime}$ S., $85^{\circ} 30$ ' w.

$80^{\circ} 40^{\prime}$ ' S., $26^{\circ} 00^{\prime} \mathrm{W}$.

$79^{\circ} 50^{\prime}$ ' S., $28^{\circ} 30$ ' W.

$73^{\circ} 12$ ' S., $75^{\circ} 00^{\prime} \mathrm{w}$.

$79^{\circ} 05^{\prime}$ S., $28^{\circ} 15^{\prime}$ ' W.

$85^{\circ} 00$ ' S., $175^{\circ} 00$ ' W.

$74^{\circ} 15^{\prime}$ S., $163^{\circ} 00^{\prime}$ E.

$79^{\circ} 00^{\prime}$ S., $100^{\circ} 00^{\prime}$ W.

$60^{\circ} 00^{\prime}$ S., $120^{\circ} 00$ ' E.

$71^{\circ} 30$ ' S., $35^{\circ} 40$ ' E.

produce Landsat single-scene and multiple-image mosaic maps (scale $1: 1,000,000$ ) of all coastal areas of Antarctica. For mapping purposes, he recognized the advantage of Landsat images, because of their synoptic view, over conventional images. For instance, only 15-20 Landsat images, instead of 12,000 conventional vertical aerial photographs, are required to cover the area of a 1:1,000,000-scale map of the International Map of the World (IMW) series (MacDonald, 1976a); the small number of images is a distinct advantage for Antarctica, where geodetic ground control is scarce. MacDonald's maps were based on unenhanced images of MSS band $7(0.8-1.1 \mu \mathrm{m}$, near-infrared); only five maps were eventually published and three additional ones were released as poor-quality ozalid reproductions through the USGS open-file report series. Unenhanced paper prints of individual Landsat images or mosaics have been extensively used in the production of preliminary

planimetric maps at scales of $1: 250,000$ and 1:500,000 by the British Antarctic Survey for the Antarctic Peninsula and adjacent regions, and by the Australian Division of National Mapping for the coastal areas of East Antarctica in Wilkes Land. However, unenhanced black-and-white paper prints generally produce satellite-image maps of lesser quality than can be achieved with modern image-processing techniques.

Digital-image mapping has been done largely for single frames, especially by Norway (International Business Machines, IBM, in Oslo and the Norsk Polarinstitutt, Ødegaard and Helle, 1982) and by New Zealand's Department of Scientific and Industrial Research (DSIR). Concurrently with the USGS effort in Flagstaff, Arizona, mosaicking by digital-imageprocessing methods is now being attempted by the Institut für Angewandte Geodaesie of the Federal Republic of Germany and by the DSIR of New Zealand (Williams and others, 1982).

\section{DIGITAL-IM AGE-PROCESSING METHODS}

Most Landsat MSS images of Antarctica produced by the Flagstaff facility are composites of band $4(0.5-0.6 \mu \mathrm{m}, \mathrm{green})$, band $5(0.6-0.7 \mu \mathrm{m}$, red), and band $7(0.8-1.1 \mu \mathrm{m}$, near infrared). In some images, band 5 was saturated, so band $6(0.7-0.8 \mu \mathrm{m}$, near infrared) was substituted. Our digital-image processing of Landsat images includes routine procedures such as radiometric corrections, noise removal, and geometric corrections (Chavez and others, 1977; Condit and Chavez, 1979). Further processing includes haze removal (Chavez, 1975) and image enhancement involving customized stretching of gray values (digital numbers) of individual MSS bands after analysis of gray-value histograms.

Saturation of snow- and ice-covered scenes in bands 4, 5, and 6 (fig. $2 \mathrm{~A}$ ) is a severe problem in Landsat MSS images (Dowdeswell and McIntyre, 1986); the saturation makes many images unsuitable for multispectral work and can even result in loss of information in all four Landsat MSS bands (Ferrigno and Williams, 1983). We have developed a restoration technique for reconstructing the information lost in bands 4 and 5 by such saturation (fig. 2B). The technique can be applied only if bands 6 and 7 retain good information. If an image contains undulating terrain, slopes facing away from the Sun have lower brightness values and are less subject to saturation than flat areas or slopes facing toward the Sun. To a first-order approximation, the spectral-color ratios of snow and ice are independent of sun-elevation angle. During the restoration, images are scanned for unsaturated snow and ice areas, and statistical relations are established among the band ratios $4 / 7$, $5 / 7$, and $6 / 7$. From these relations, bands 4 or 5 can be predicted as a function of the $6 / 7$ and $4 / 7$ or $5 / 7$ ratios and the intensity of band 7. A second pass through the data applies these functional relations to saturated areas. For images having insufficient areas of unsaturated snow and ice, the functional relation from other less saturated images can be applied.

Comparison of an unenhanced paper print of MSS band 7 of the Jutulstraumen Glacier in Queen Maud Land (fig. 3A) and a digitally enhanced multispectral 


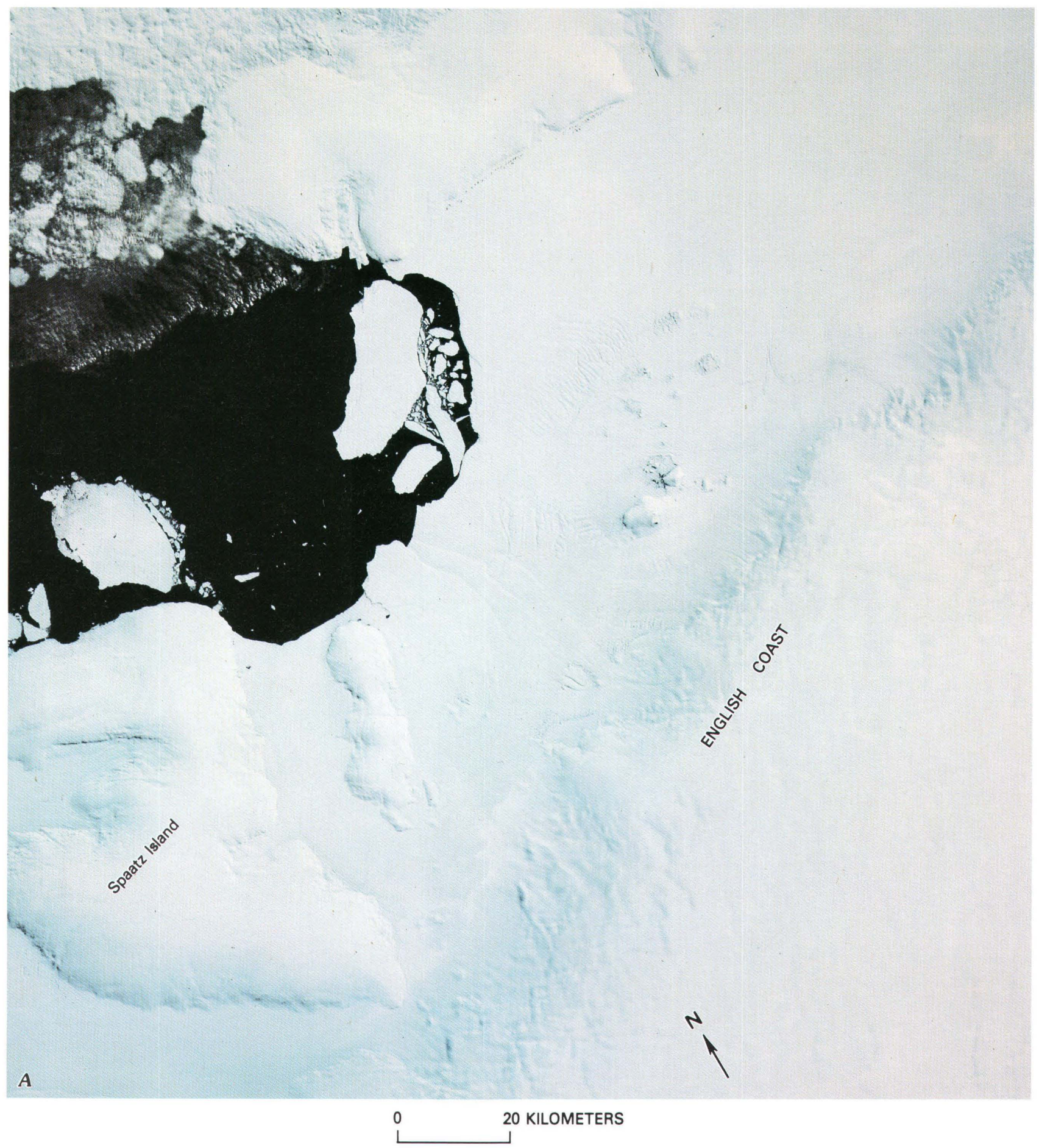

Figure 2. Saturated and saturation-corrected composites of bands 4, 5, and 7 of Landsat 1 MSS image $1170-$ 12260, 9 January 1973. Part of base of Antarctic Peninsula; English Coast separates the Antarctic continent on right from ice shelf on left. A, Composite of saturated bands 4 and 5 and unsaturated band 7 . B, Composite in which bands 4 and 5 have been restored from information in unsaturated parts of bands 4, 5, 6, and 7; a high-pass filter was applied to enhance fine detail. 


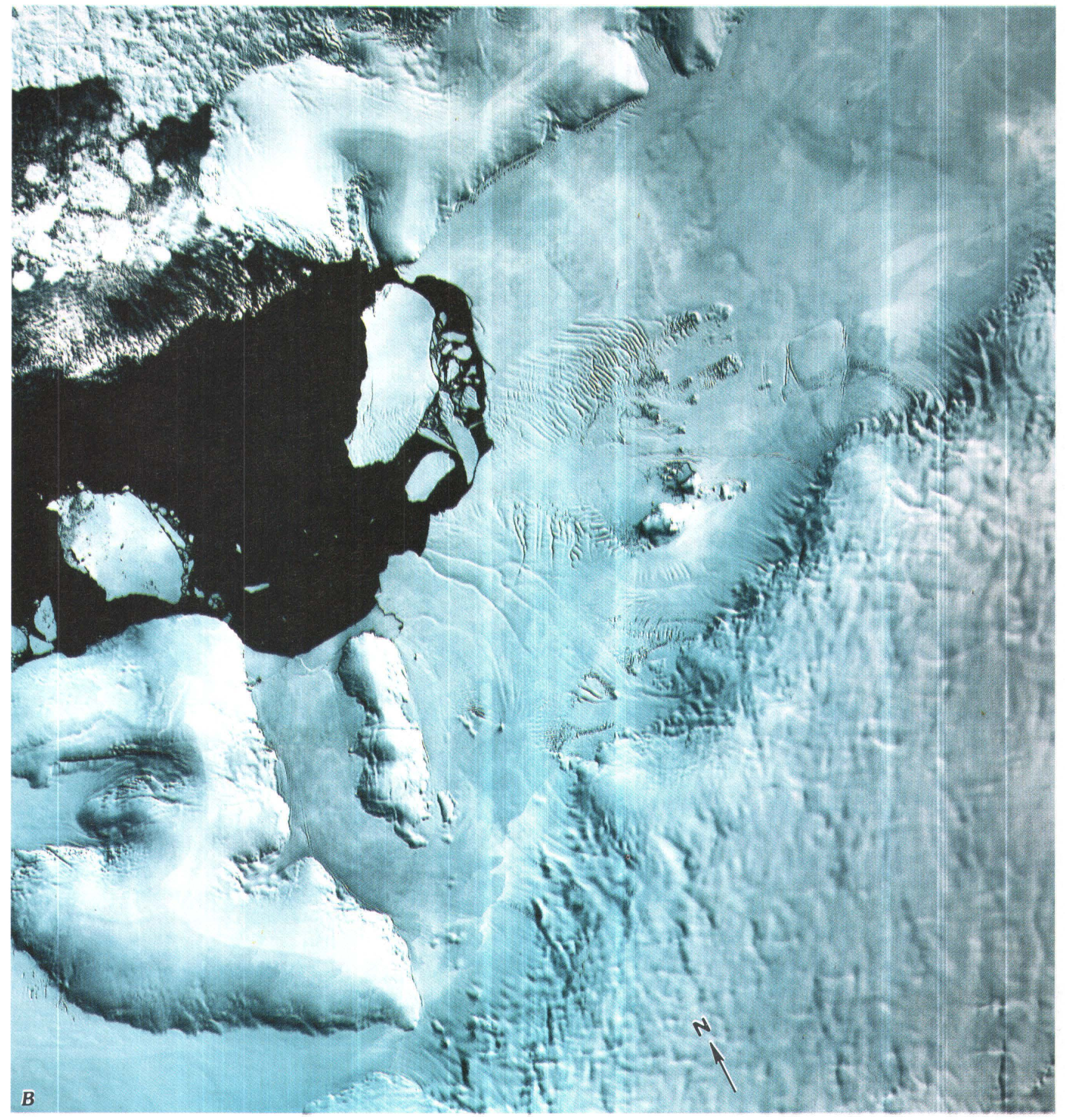

Figure 2. Continued. 20 KILOMETERS 


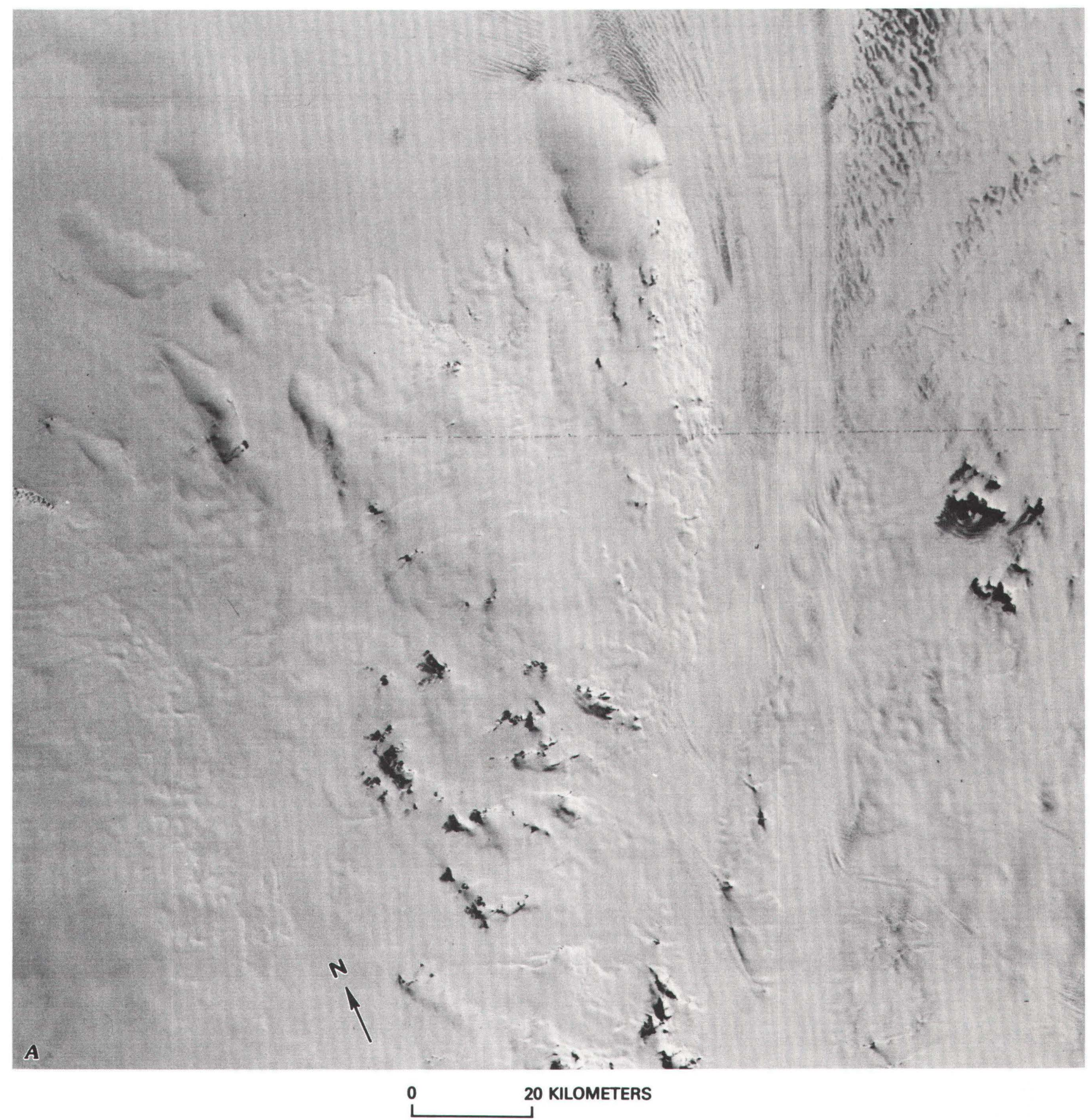

Figure 3. Paper print of unenhanced MSS band 7 (A) and digitally enhanced composite of bands 4,5 , and 7 (B) of Landsat 2 MSS image 2281-07424, 30 October 1975. Jutulstraumen Glacier in Queen Maud Land in right center of pictures, flowing north. Enhanced image B shows improved definition of flow lines in glacier, wind streaks crossing glacier (lower right center), and undulation of ice sheet. Blue-ice areas (examples indicated by arrows) show as blue patches. 


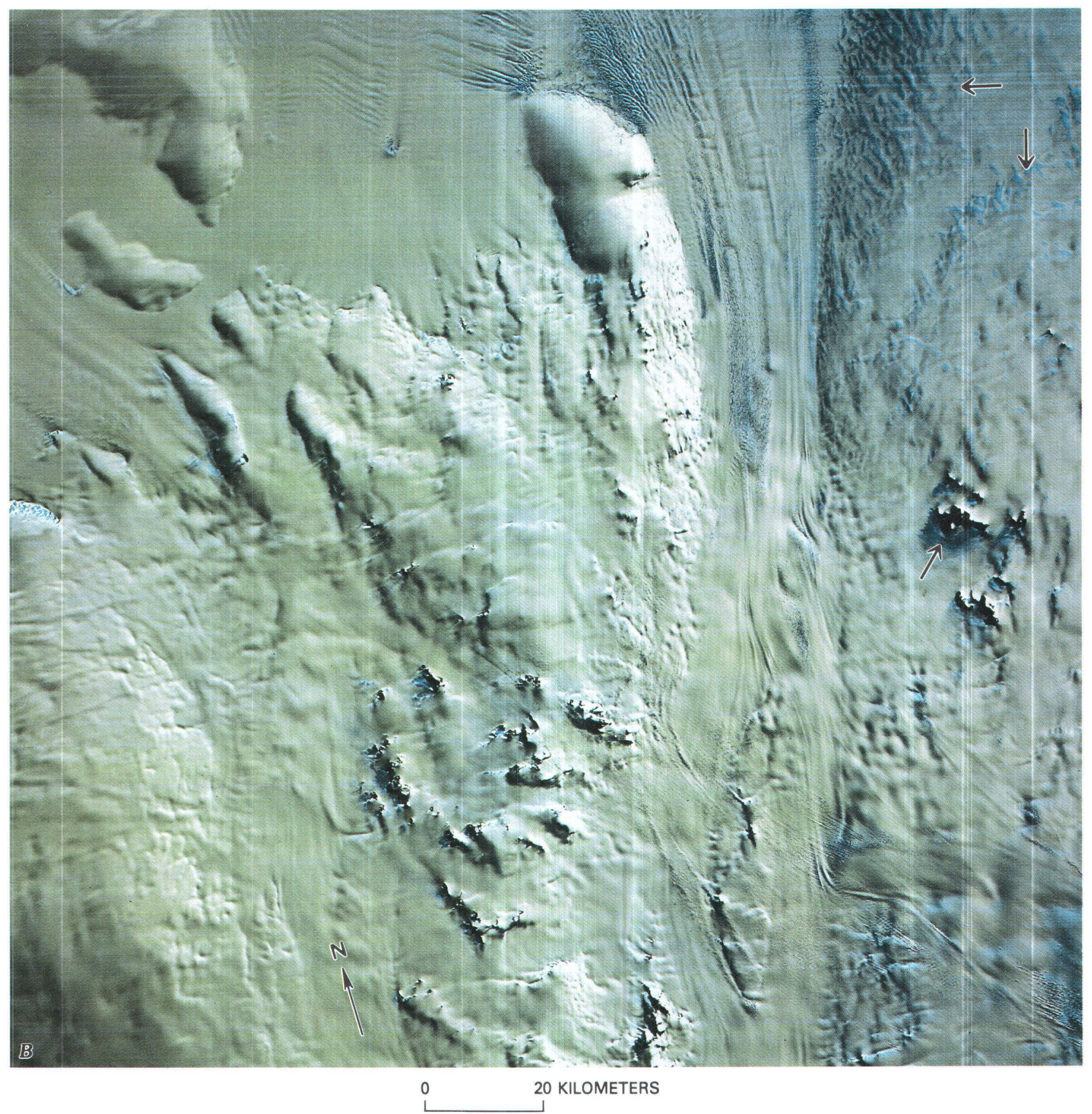

Figure 3. Continued. 
image of the same scene (fig. $3 \mathrm{~B}$ ) shows that the enhanced image provides much more detail.

A digitally enhanced mosaic of the McMurdo Sound region is shown in figure 4. As is evident in this mosaic, the digital method permits the automated removal of seams (boundaries between Landsat images) and the matching of different tones in the various images used to construct the mosaic. Tone matching is particularly crucial for images of Antarctica because the varied, yet low, solar-elevation angles create scenes that differ markedly in spectral response. To lighten the dark rocky outcrops and to darken the bright sunny areas, we applied a high-pass filter and reduced the contrast by 50 percent (Chavez and Berlin, 1984). The mosaic shows much more detail in rock outcrops of the Dry Valleys than can be seen on unenhanced, monochrome Landsat images. Furthermore, bare ice can be dist inguished from snow by its blue color, and fine morphologic features such as flow lines and crevasses on glaciers are clearly visible. The mosaic is a false-color composite, even though the colors look real. In Antarctica, which lacks vegetation, false-color images resemble those of true color because the false red color that commonly reflects vegetation is absent.

Digital-image processing also permits the placing of geodetically controlled mosaics onto map projections. The McMurdo mosaic, for instance, is in Lambert conformal conic projection and covers the area of four complete and two partial 1:250,000-scale topographic maps. Where geodetic ground control is adequate, the mosaic has a geometric accuracy of an average of two to three picture elements (pixels) or about $200 \mathrm{~m}$.

Digital-image processing also allows the construction of hybrid maps, for which images can be superposed on other data such as digitized topographical, geological, geophysical, geochemical, or other remote-sensing information. Superposed data sets can be displayed graphically and correlated visually or by computer methods. Superposition techniques have been used for geologic interpretations in areas of the United States (Arvidson and Guinness, 1981; Trautwein, 1983) but have not yet been tried for Antarctica. Several geophysical surveys of Antarctica are in progress (Behrendt, 1983) for which our digital-image mosaics will serve as planimetric base maps for display and correlation of geological, geophysical, and glaciological data.

\section{SPECIAL-PURPOSE IMAGES}

In Antarctica, where vast regions are difficult to reach on the ground, the location of features by remote-sensing techniques becomes important. To this end, the multispectral digital images can be converted into thematic images that delineate features of interest. Figure $5 \mathrm{~A}$ shows an image of the Byrd Glacier and environs in which soil or rock outcrops are highlighted. The image was prepared by first producing versions showing the ratios of MSS bands $4 / 5,5 / 6$, and $6 / 7$ for each pixel in the image. An unsupervised classification program of the ratioed images then separated snow from ice and from soil or rock. On the basis of these distinctions, the soil-or- rock image was prepared. Each pixel showing soil or rock was enlarged to a 5-by -5 pixel area, for easier recognition. The image shows that a strip in shadow along the north side of the Mulock Glacier contains soil or rock exposures that are not plainly visible on the original Landsat MSS image. Because atmospheric scattering and back lighting cause a shadow on snow to have a different signature than a shadow on soil or rock, spectral techniques can discriminate these two types of materials. Soil or rock maps can thus be produced even in areas where much of the surface may be in shade because of low solar-elevation angles.

Ice can also be highlighted in special-purpose images (fig. 5B) by the same method. Conspicuous in this "ice-only" image are the icy parts of the Byrd Glacier, which show crevassed areas concentrated in the narrowest part of the glacier.

\section{ANTARCTIC METEORITES}

Of particular interest in recent years has been the search for meteorites in Antarctica, and multispectral Landsat images may help in this effort. About 6,000 meteorite fragments have been recovered from Antarctica, mostly in blue-ice areas. Of these meteorites, 4,000 were found by Japanese parties working in the Yamato and Belgica Mountains and 1,200 by U.S. scientists near the Allan Hills and other areas inland of the Transantarctic Mountains in southern Victoria Land (National Science Foundation, 1981; Bull and Lipschutz, 1982). These numbers represent 25 percent of the total meteorite finds on Earth (Williams and others, 1983). Olsen (1981) estimated that at least 760,000 meteorites are likely to lie within the ice sheet of East Antarctica.

Blue ice is a distinctive turquoise blue. Exposures occur in many parts of Antarctica, primarily near the coast and in the interior both upstream and downwind from nunataks. The ice exposures are caused by ablation, which results mainly from sublimation, wind scouring of the snow mantle, and surface polishing by wind-driven snow (Williams and others, 1983). Whillans and Cassidy (1982, 1983) proposed a meteorite-concentration mechanism in which meteorites fall into accumulation areas and are buried. Meteorites are then carried along in the moving ice sheets and reappear in the blue-ice areas, where the surface is reduced by ablation and the flow is highly strained, compressed, and pushed upward because of its blockage by transverse mountain ranges. Meteorite concentrations are thus a lag deposit on blue ice (Marvin, 1982). Areas of high strain rates are predictable from the geometry of a flow and from the recognition of obstacles and entrained debris in the flow path, both of which can be identified locally on Landsat images.

Blue ice shows exceptionally well on multispectral Landsat images. The signature of blue ice is distinct from that of rock in Landsat MSS bands 4 and 5; however, the signatures are similar in bands 6 and 7. There fore, on paper prints of MSS band 7--used extensively in the past--blue ice is difficult to differentiate from rock, and misidentifications have been made (Southard and Mac Donald, 1974). Figure 6 shows the Allan Hills area of southern Victoria Land 


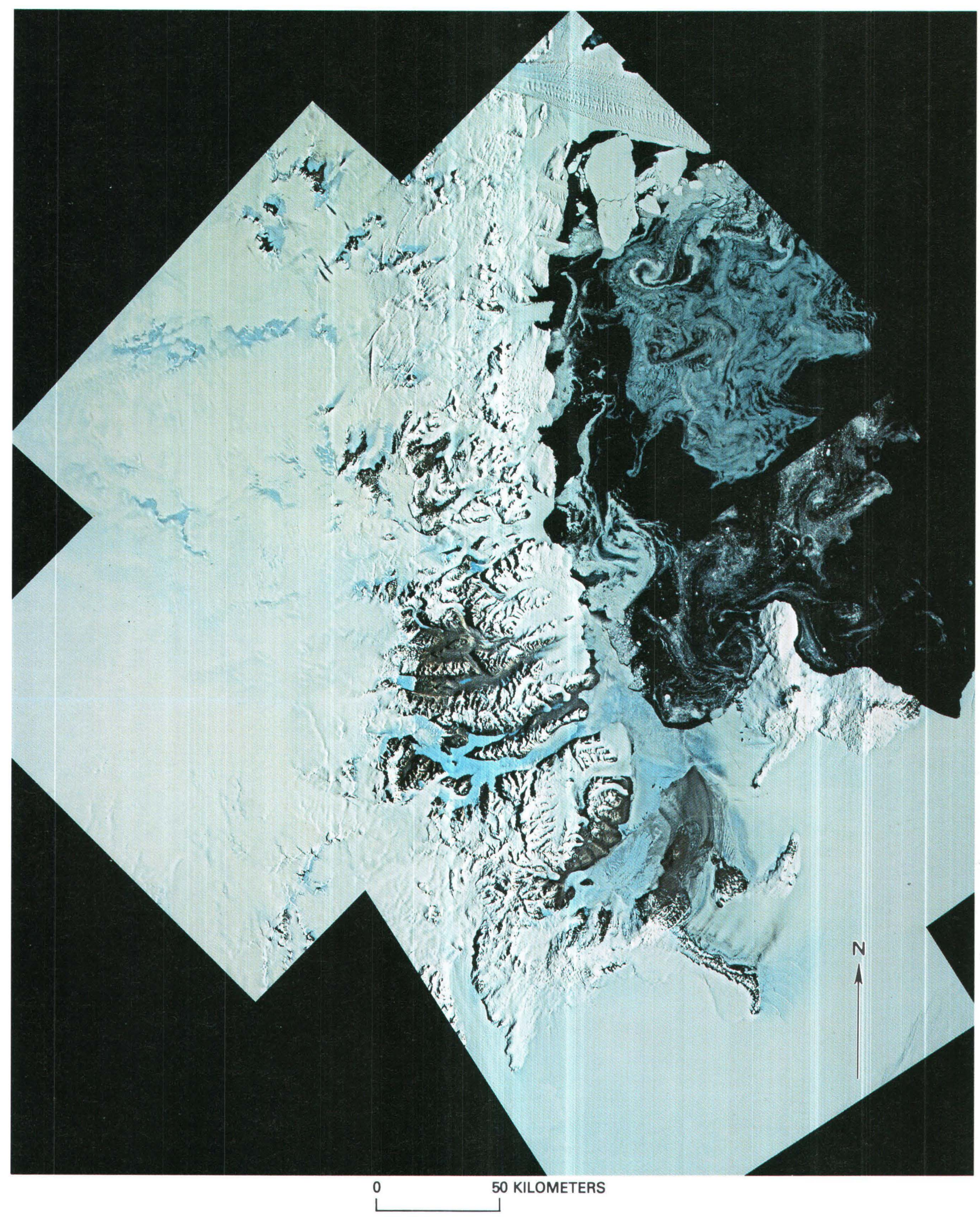

Figure 4. False-color multispectral digital mosaic of McMurdo Sound region in Lambert conformal conic projection. Ross Island, snow-covered area in right center, is topped by active volcano Mount Erebus (left center of island). Mc Murdo Station on the island is located at tip of fingerlike peninsula extending toward southwest. Ice-free valleys in center of image are Dry Valleys. (Mosaic of Landsat MSS images 1214-20064, 22 February 1973; 1520-20034, 25 December 1973; 1529-19121, 3 January 1974; 1531-19231, 5 January 1974; 154020141. 14 January 1974; 2279-19361, 28 October 1975; composites of bands 4, 5, and 7.) 


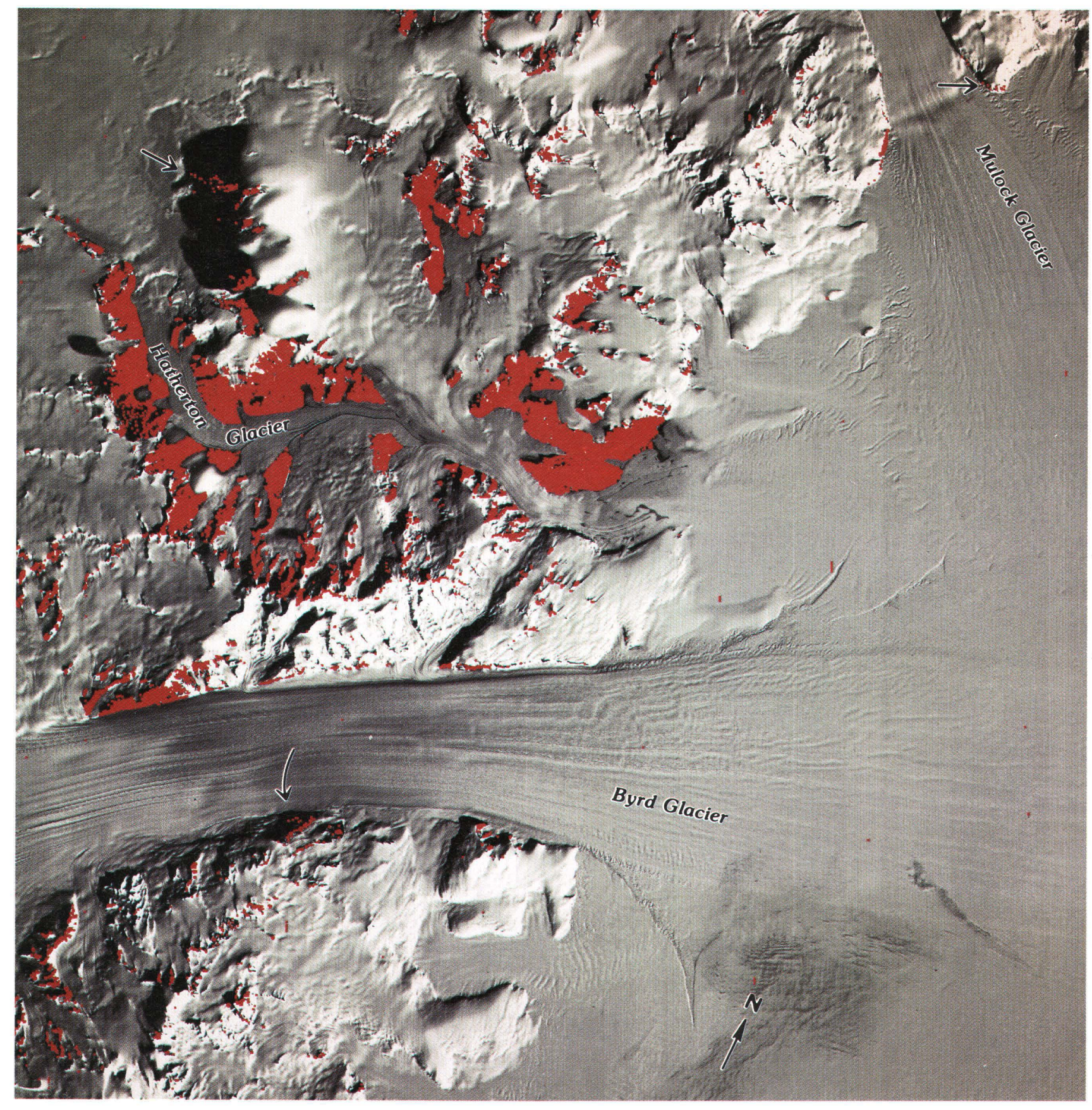

20 KILOMETERS

Figure 5. Byrd Glacier region. Band 7 of Landsat 1 MSS image 1542-18435, 16 January 1974 . A, Specialpurpose image highlighting areas of soil or rock exposure (red). Note rock exposures in shadow (examples shown by arrows). Diffused light and dark areas in top left of picture are clouds and their shadows. Isolated red spots on glaciers are computer errors. B, Special-purpose image highlighting areas of bare ice (blue) on Hatherton Glacier, in highly crevassed area in center of Byrd Glacier, and along edge of crevasses. Blue spots near bottom right of image are computer errors. 


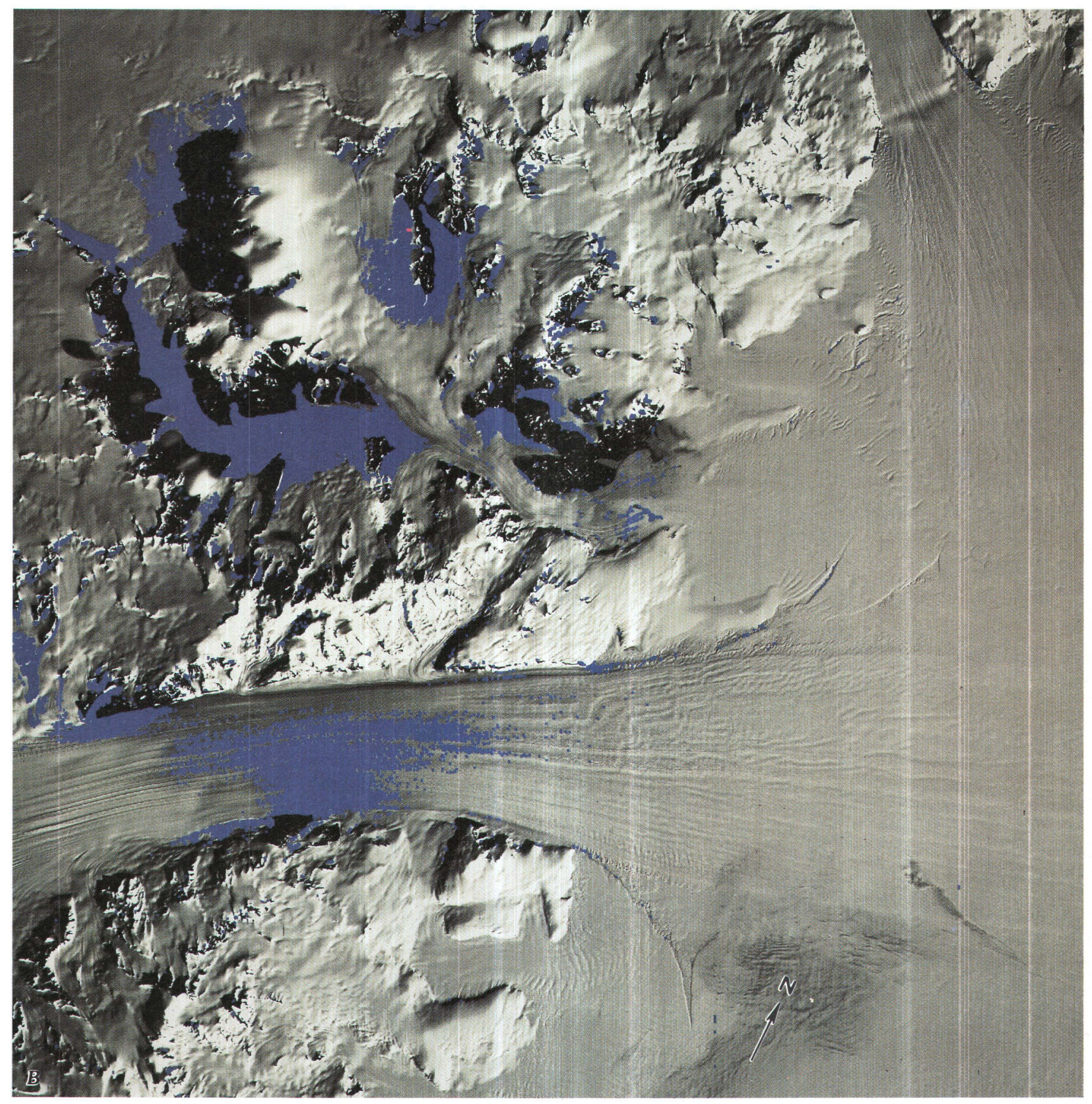

0

20 KILOMETERS

Figure 5. Continued. 
and the blue-ice area where meteorite searches by the United States have been targeted (Cassidy, 1979). The search efforts have been expanded to other blue-ice areas in the vicinity, and the image map shown in figure 6 is being used to locate additional areas (W.A. Cassidy, University of Pittsburgh, written commun., November 25, 1985). Another Landsat image of the area was successfully used during the search for meteorites in the $1982 / 83$ austral field-work season to plot traverses and to identify blue-ice patches where meteorites were collected (Meunier, 1983). Special blue-ice maps covering all coastal and nunatak areas of Antarctica would be extremely help ful for expanded future searches for meteorites. The use of Landsat images to prepare these maps was highly recommended during a workshop on Antarctic glaciology and meteorites (Bull and Lipschutz, 1982).

\section{GLACIOLOGICAL CONTRIBUTIONS}

The synoptic view afforded by Landsat images is especially useful for the recognition and identification of glaciological features. For instance, Orheim (1978) found several ice $r$ ises on Landsat images of Queen Maud Land. Ice rises (figs. 7 and 8) are generally ellipsoidal, dome-shaped ice caps grounded on shoals within or at the seaward edge of ice shelves (Armstrong and others, 1973); they are nourished almost exclusively by local accumulation of snow. Their shape and dynamics have been studied intensively because they are smaller analogs to the large ice sheets that cover Antarctica; study of ice rises may contribute to a better understanding of the flow mechanism of the large sheets (Bentley and Giovinetto, 1962; Clapp, 1965; Budd, 1969). A controversy has developed concerning the profiles across several of these ice rises: Landsat images show that many of the rises have distinct ridges along their crestlines (Martin, 1976), even though flow laws predict flattened crests whose slopes are close to $0^{\circ}$ (Nye, 1959; Paterson, 1981). Martin (1976) proposed that a ridged crest indicates that a critical stress in the ice has to be reached before the ice begins to deform. However, detailed profiles across ice rises, prepared in a followup study on the shape and dynamics of ice rises (Martin and Sanderson, 1980), showed no topographic ridges along their crests. Our digitally enhanced Landsat images clearly show not just single, but double ridges on several ice rises (figs. 7 and 8). The ridges are not artifacts, because they can be seen in other images taken several years apart. The ridges follow sweeping, broadly sinuous curves along the ice-rise crests. They are superposed on topographic ir regularities, which suggests that they are relatively late, perhaps even ephemeral, features. Their apparent youth and sinuous shape suggest that they may be caused by wind action, perhaps by a combination of wind sculpture and deposition of drifts. Mars, whose environment is a cold desert like Antarctica, has many sweeping sinuous scarps and ridges, which are commonly interpreted as being due to eolian processes (Cutts and Blasius, 1981). Future ground investigations will have to elucidate the precise nature of the ice ridges in Antarctica. The configuration of ice-rise crests needs to be determined because it affects calculations concerning the mass balance of ice caps.

As pointed out by Swithinbank and Lucchit ta (1986), digitally enhanced Landsat images show--more clearly than previous images--synoptic views of glacial flow lines and ice rumples (bedrock highs in the path of ice streams and ice shelves over which the ice moves and is deflected upward). The Kershaw Ice Rumples (bottom of fig. 7) form as a thick ice shelf forces its way over a shoal. Crevasse fields on the downstream side are also visible. Figure 7 also shows on the Ronne Ice Shelf flow lines persisting for hundreds of kilometers from their sources. The flow lines represent sutures recording the confluence of discrete ice streams and the path along which the ice has moved (Swithinbank and Lucchitta, 1986). Surface markings on ice streams tend to develop transverse ridges beyond the grounding line where the ice stream begins to float. Divergence of flow lines around subtle highs in floating ice streams and ice shelves indicates possible places of grounding, and several such sites have been detected on our images (fig. 8). The location of grounded ice in ice streams and ice shelves is important in the analysis of the dynamics of the ice sheets, and changes in grounded areas may indicate long-term climatic changes (Hughes, 1983).

Digitally enhanced Landsat images, which show subtle relief variations on the ice surface, may also delineate the extent of some buried mountain ranges and indicate the underlying structure (Marsh, 1985). The image in figure 8 shows buried valleys upstream from two glaciers that enter the Rutford Ice Stream from the west and also a series of escarpments at the edge of the Ellsworth Mountains over which these glaciers drop before joining the Rutford Ice Stream. At the surface of the Slessor Glacier (fig. 9), a pronounced diagonal bedrock structure is clearly expressed; the scarp on the glacier is probably the surface expression of a fault in the subglacial bedrock. In this image buried valleys also show well through the ice cover.

\section{COASTLINE CHANGES}

The synoptic view of Landsat images is well suited to the monitoring of dynamic Antarctic features such as shorelines, grounding lines, ice-shelf margins, position of glacier tongues and ice streams, and seaice distribution. Even though repeated coverage of these features using photographs from aircraft would serve the same purpose, the logistics of such surveys would be difficult; repeated routine coverage by satellite at fixed time intervals is definitely advantageous. Monitoring the coastline for changes with time helps detect changes that reflect the waxing and waning of the ice sheets and that may thus have far-reaching implications for world climate.

MacDonald (1976b) recognized the value of Landsat images for the monitoring of coastline changes and gave several examples of changes: The Erebus Glacier Tongue on Ross Island (fig. 4), which broke off in 1911, has advanced $9.6 \mathrm{~km}$ between 1947 and 1972, when the first Antarctic Landsat images were acquired. By comparing published maps and 


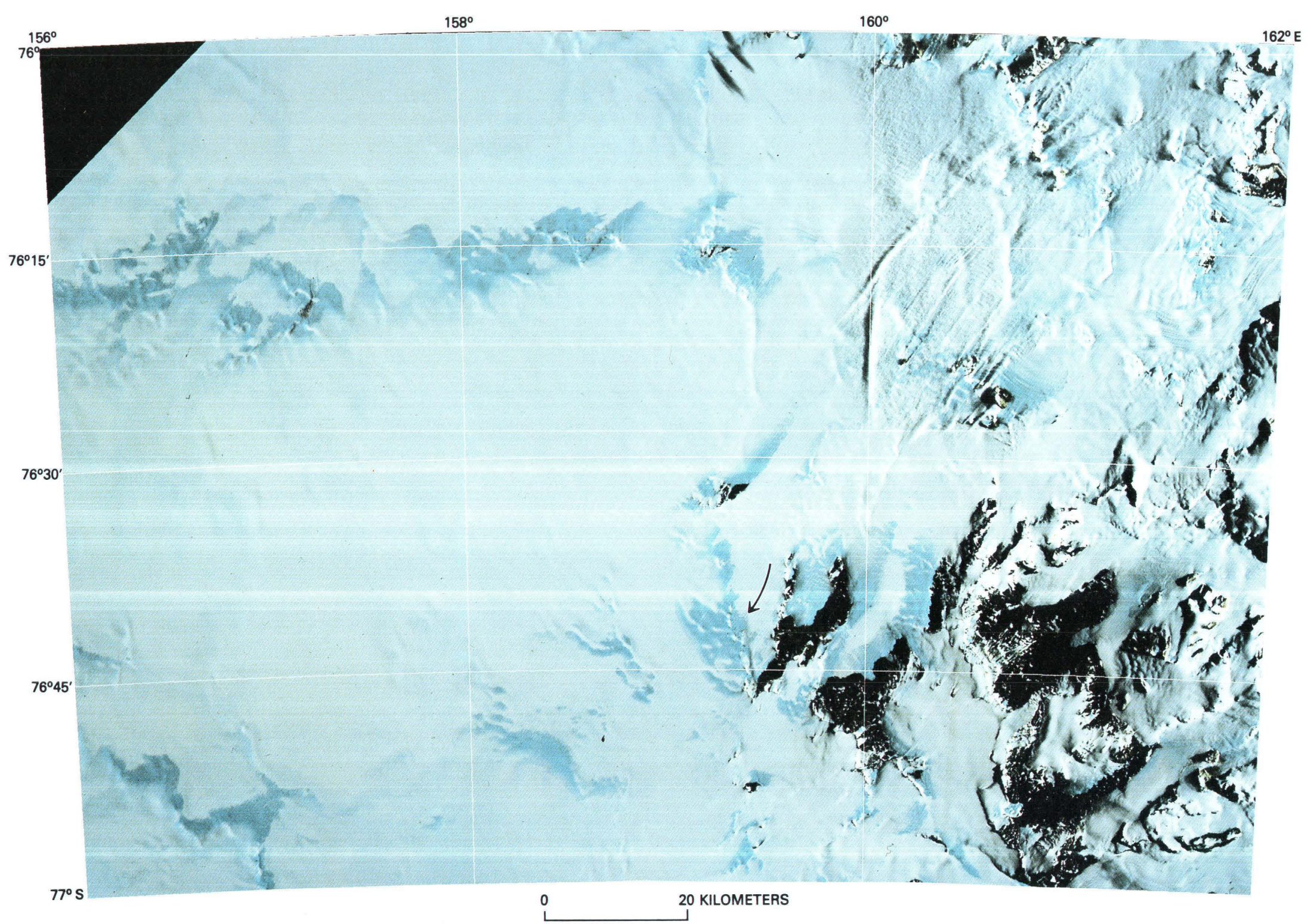

Figure 6. False-color multispectral image map of the Convoy Range quadrangle, polar stereographic projection. Excerpt of mosaic shown in figure 4 . Allan Hills are dark horseshoe-shaped rock exposure at lat $76^{\circ} 43^{\prime}$ S., long $159^{\circ} 40^{\prime}$ E. Blue-ice areas are turquoise blue. Meteorite-collecting sites in blue-ice patch at

arrow. Hummocky, striated, light-colored area near top right is cloud cover; dark streaks are cloud shadows. (Mosaic of Landsat MSS images 1214-20064, 22 February 1973; and 1540-20141, 14 January 1974 ; composites of bands 4,5 , and 7 .) 


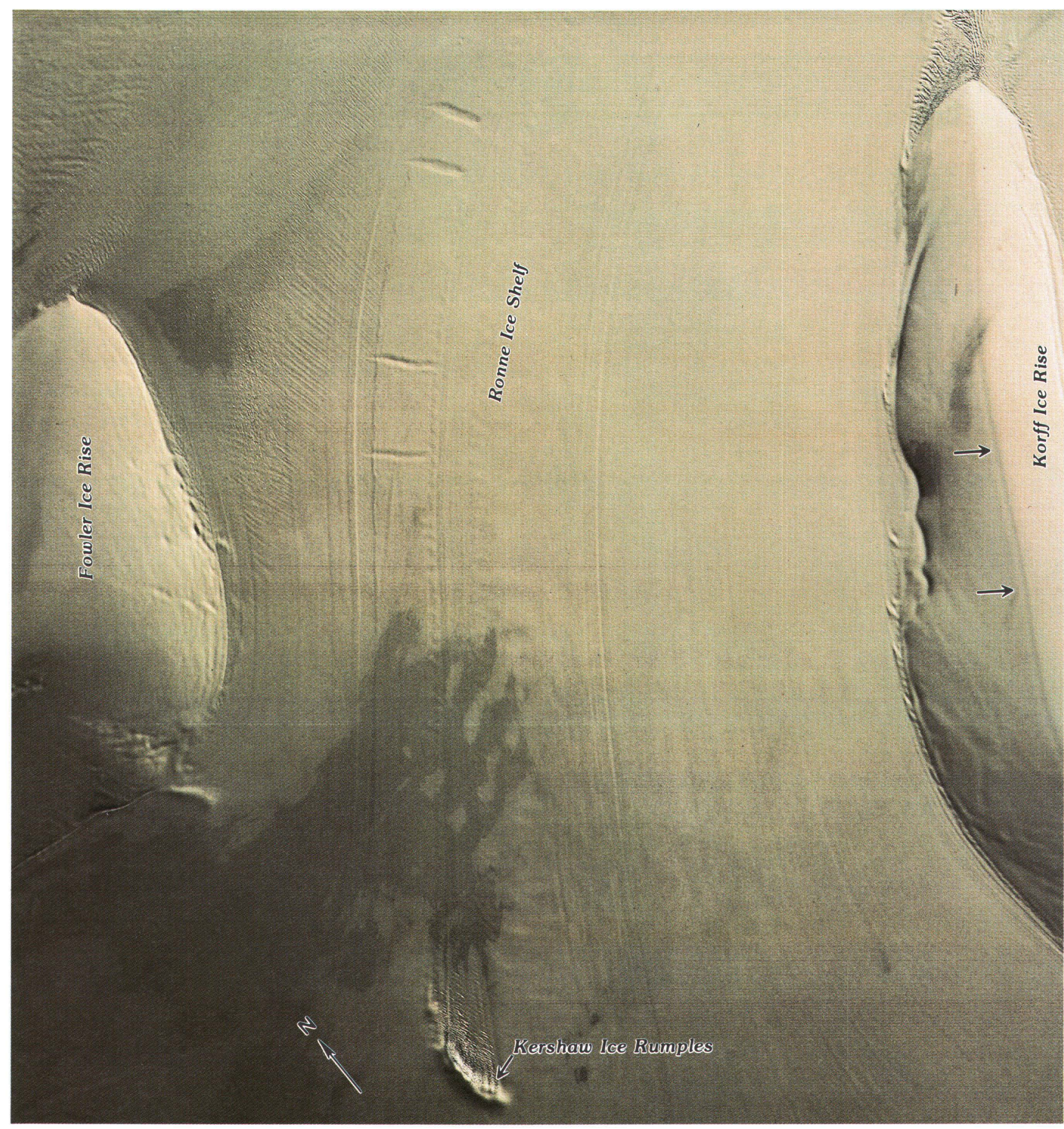

Figure 7. Glaciological features on Ronne Ice Shelf. Digitally enhanced composite of bands 4, 5 , and 7 of Landsat 1 MSS image 1570-11031, 13 February 1974. Note double ridge (arrows) on crest of Korff Ice Rise. Flow lines trending northeast represent sutures recording confluence of discrete ice streams outside picture. Kershaw Ice Rumples show extensive crevasse field at downstream (northeast) side. Dark patches at bot tom left are of unknown origin, but they could represent thin layer of drifting snow or area of recently deposited but uncrystallized snow of lower albedo (Swithinbank and Lucchitta, 1986). 


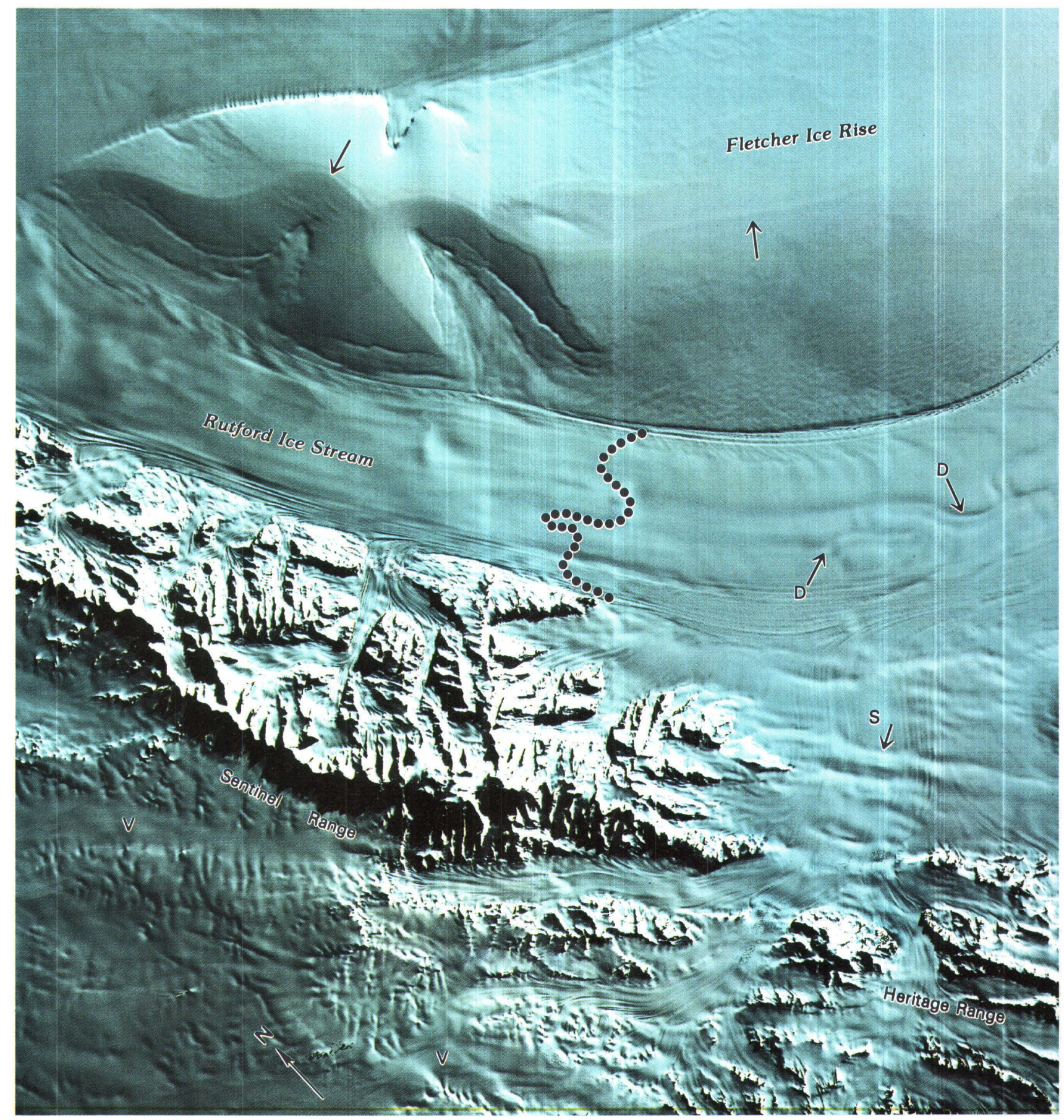

0

20 KILOMETERS

Figure 8. Morphological features in Sentinel Range in Ellsworth Mountains and Rutford Ice Stream. Composite of bands 4, 5, and 7 of Landsat 1 MSS image 1560-11492, 3 February 1974. Image is digitally enhanced to bring out detail in snow and ice; however, detail of rock outcrops is suppressed by this method. Note double ridge (arrows) along crest line of Fletcher Ice Rise. Grounding line of Rutford Ice Stream (dots) after Stephenson and Doake (1982). Ice stream flows from left to right. Note contrast between its sliding part (left of grounding line), which displays linear flow markings, and its floating part (right of grounding line), which displays linear and transverse markings. D, sinuous depressions formed where floating ice stream slides over suspected shoal; V, buried valleys upstream from glacier entering Rutford Ice Stream from west; S, scarps in buried mountain ranges visible through ice cover. 


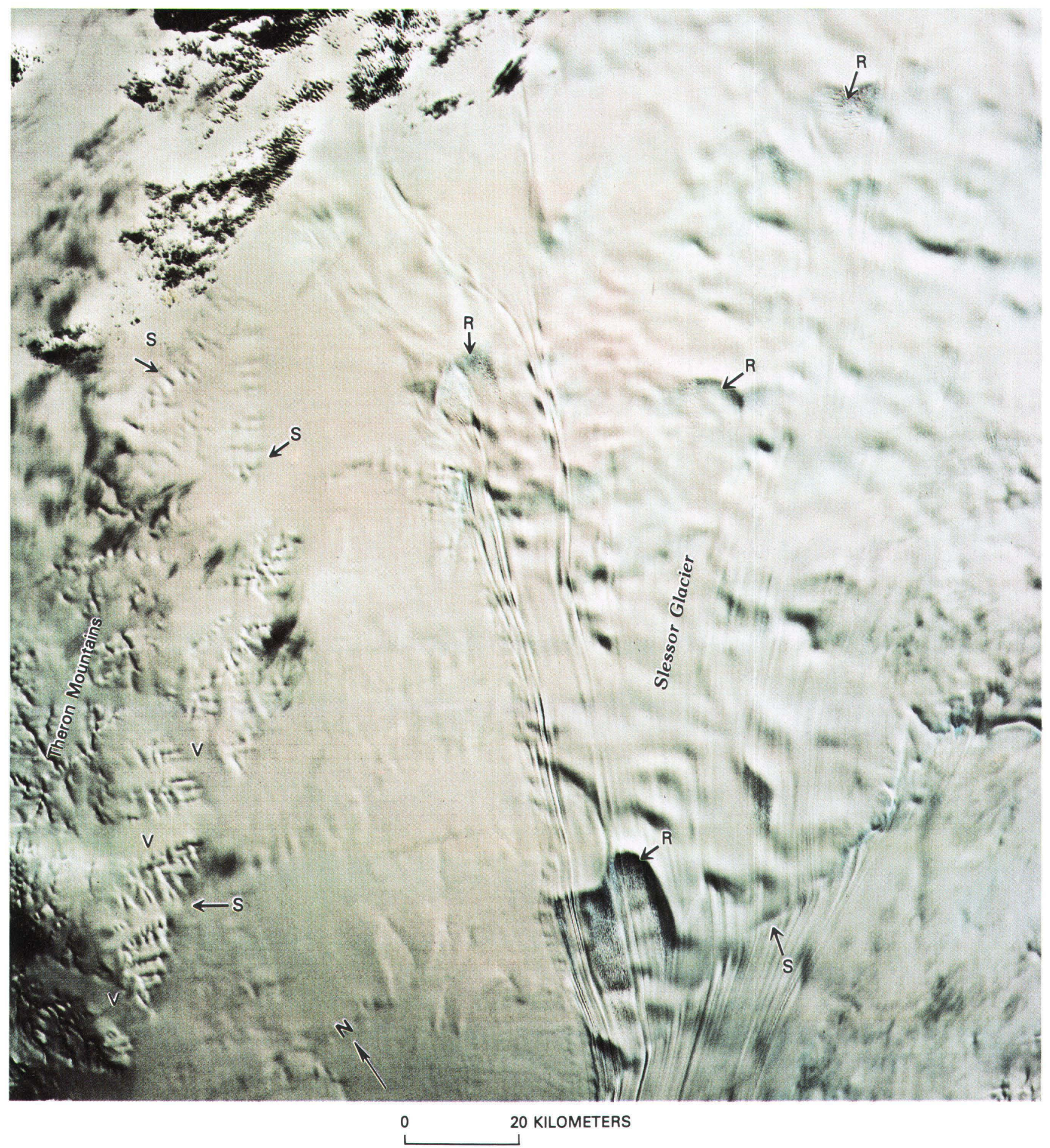

Figure 9. Morphological features in Theron Mountains and Slessor Glacier. Digitally enhanced composite of bands 4, 5, and 7 of Landsat 1 MSS image 1548-07145, 22 January 1974. Glacier flows southwest. Note influence of subglacial morphology and structure on surface of glacier and ice sheet to its left. S, linear scarps along Theron Mountains and across Slessor Glacier; may be expressions of subglacial fault lines. R, ridges in ice and associated extensive crevasse fields; probably mark bedrock obstacles in flow path. V, valleys in Theron Mountains visible in spite of ice cover. Light and dark mottling at bot tom right and top left caused by clouds. 
aerial photographs with Landsat images, MacDonald noted that the margin of the Ronne Ice Shelf had advanced $16 \mathrm{~km}$ between January 1966 and February 1973; however, this measurement may have been in error because of inaccuracies in the map. Ferrigno and others (1983) determined the velocity of the Pine Island Glacier, a tidal-outlet glacier on the West Antarctic coast: During the 750-day interval represented by repetitive Landsat images, the terminus moved about $4.5 \mathrm{~km}$, at an average velocity of $6 \mathrm{~m}$ per day. This glacier is a large ice stream draining the ice sheet of West Antarctica. It is presently surging, apparently having punched through a confined and pinned ice shelf (Hughes, 1981; Stuiver and others, 1981). Such surges can have profound effects on the mass balance of the ice sheets, and their periodic monitoring is essential.

Our studies show that the Ferrar Glacier of southern Victoria Land retreated $3 \mathrm{~km}$ between 1957 and 1983, an average of 110 meters/year. This assessment is based on Landsat images taken in 1975 and conventional photographs taken in 1957 and 1983. Landsat images of the Byrd Glacier, also in southern Victoria Land, taken in January 1974 and November 1983 depict a large crevasse where the glacier enters the Ross Ice Shelf (fig. 10). This shear-rupture crevasse (Hughes, 1983) opened $700 \mathrm{~m}$ in the 10 years between the acquisition of the two images. Hughes (1983) pointed out that the study of crevasses in ice shelves is important because crevasses serve as focal points for ice-shelf disintegration. The floating part of Byrd Glacier moved about $8.0 \mathrm{~km}$ in this 10 -year interval, or an average of 800 meters/year, as determined by transverse depressions that maintained their identity in the glacier (fig. 10). Our rate agrees with rates measured on the ground by Swithinbank (1963), Hughes (1977), Hughes and Fastook (1981), and Brecher (1982).

Considerable changes have been observed along Antarctic coastlines, and their documentation significantly helps both in the interpretation of the dynamics and mass balance of ice sheets and ice shelves and in the forecasts of anticipated changes. The monitoring is especially important for the ice sheet of West Antarctica, which overlies a bedrock surface of considerable relief (including many volcanoes); 70 percent of this surface is below sea level (Znachko-Yavorskiy, 1978). The condition of the ice sheet is there fore thought to be inherently unstable (Hughes, 1973; Weertman, 1974). Increased calving of ice fronts on the shelves might cause surging of ice streams, a negative mass balance of the ice sheet, retreat of the grounding line, and rapid disintegration of the ice sheet (Stuiver and others, 1981). Disinteg ration of the ice sheet of West Antarctica may lead to a significant rise in sea level, as much as $3.5 \mathrm{~m}$, along the coastlines of the world according to Hoffman and others (1983). Monitoring the coast line region and ice shelves of Antarctica is clearly an important task (Williams, 1985). Because most Landsat images of Antarctica were acquired in the early to mid-1970's, data representing a 10 -year time lapse are already available for comparative analysis.

\section{SPECTRAL AND STRUCTURAL STUDIES}

Outcrop areas in Antarctica are small: only 2.4 percent of Antarctica is free of ice (Drewry and others, 1982). Because most of the bedrock crops out in small nunataks, the Landsat MSS images, which have a resolution of about 80 meters/pixel, are not well suited to the analysis of rocks by spectral methods. However, some preliminary research on spectral analysis of Landsat MSS images of the Dry Valleys area of Antarctica and correlation with field samples has been achieved by C. S. Southworth of the USGS (Ferrigno and others, 1983). The 30-meter/pixel resolution of thematic mapper (TM) images of Land sat 5 will probably be adequa te for spectral studies.

As with Landsat images of other areas on Earth, some images of Antarctica show distinct structural trends that, when combined with other types of geological studies, aid in geological interpretation. In spite of the ice cover, the structural orientation can be seen clearly in some mountainous regions (fig. 9). To our knowledge, only one extensive study of structural features in Antarctica based on Landsat data has been completed (Rivereau, 1978). Our enhanced multispectral images of Antarctica (figs. 8 and 9) show many linear features. A conspicuous lineament signaling a probable structural discontinuity of unknown origin shows clearly on figure 11 . Such images will prove useful in future geological or structural analyses.

\section{CONCLUSIONS}

Digitally enhanced Landsat MSS images are a significant improvement over the commonly used black-and-white paper prints of MSS band 7. They show considerably more detail in surficial morphology and shed light on many Antarctic scientific problems. Our studies show that the images are particularly helpful for the preparation of accurate color planimetric maps, which may serve as base materials for the superposition and correlation of other types of geological data. Thematic maps that show, for instance, only rock or only ice areas depict the location of desired features with a minimum of effort. Blue-ice areas, important in the search for Antarctic meteorites, are easily located on the multispectral images. The synoptic view of the images and mosaics provides several kinds of data: information on the flow lines associated with ice streams; the location of ice rises, ice rumples, and other possible grounded areas; and the extent and structural orientation of some buried mountain ranges. Monitoring the coast line for changes with time may indicate waxing or waning of the ice sheets; such changes may have far-reaching implications for variations in world climate. Overall, mult ispectral digital Landsat images are extremely helpful in Antarctic research, and we hope that increased use of them in the future will significantly aid in the exploration of that continent. 


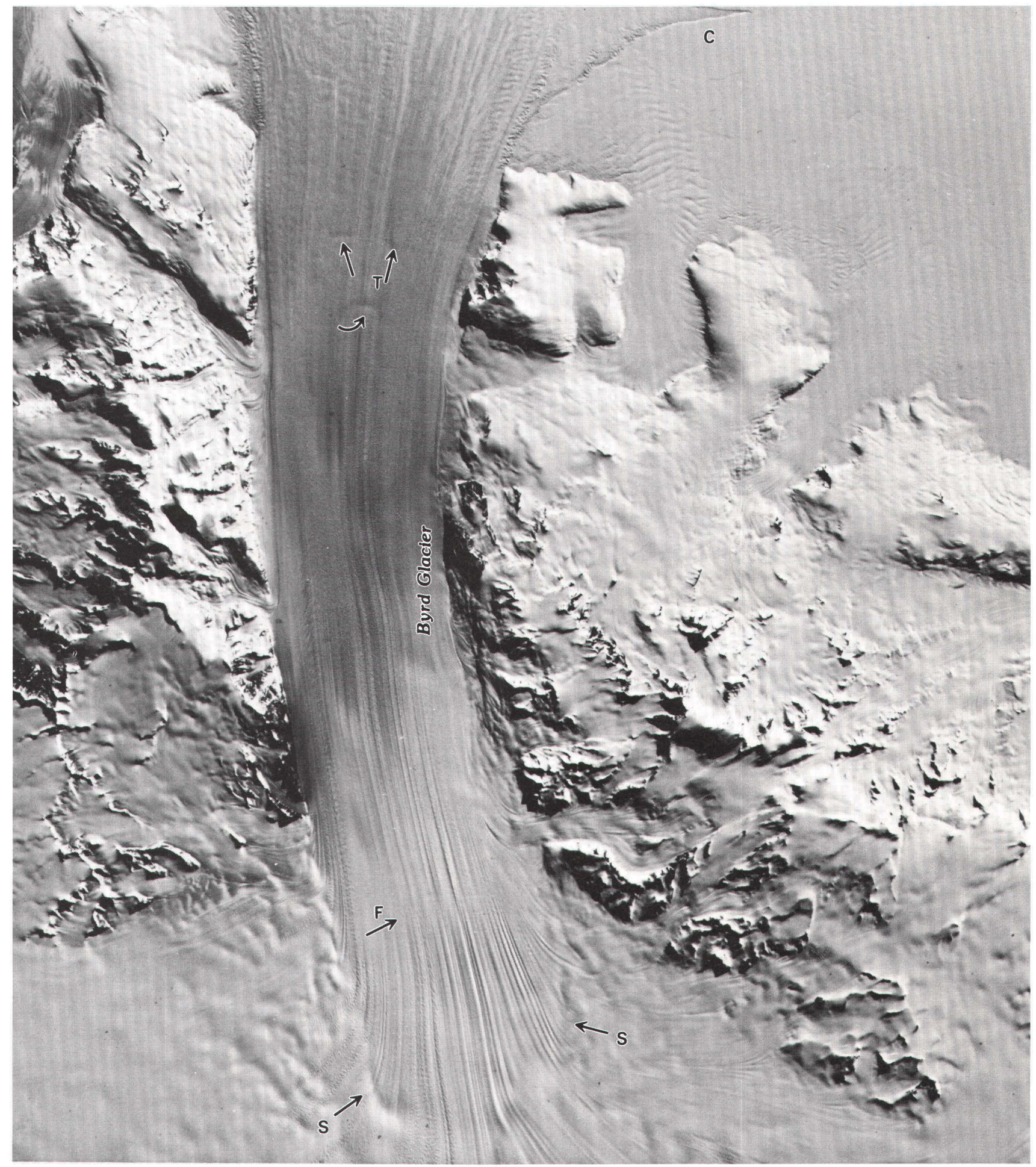

0 20 KILOMETERS

Figure 10. Enhanced image of Byrd Glacier region. Excerpt of composite of bands 4, 5, and 7 of Landsat 4 MSS image 40495-18544, 23 November 1983. Compare this image with those of figure 5, acquired almost 10 years earlier. In 10 years, crevasse (C) moved about $1.5 \mathrm{~km}$ toward ice shelf (top of picture) and opened $700 \mathrm{~m}$; transverse ridges $(\mathrm{T})$ on glacier moved about $800 \mathrm{~m}$. Note break in density of flow lines at $\mathrm{F}$; this change, so far unexplained, has not moved in 10-year interval. Also note cirquelike bedrock sill (S) over which glacier spills where entering mountains. 


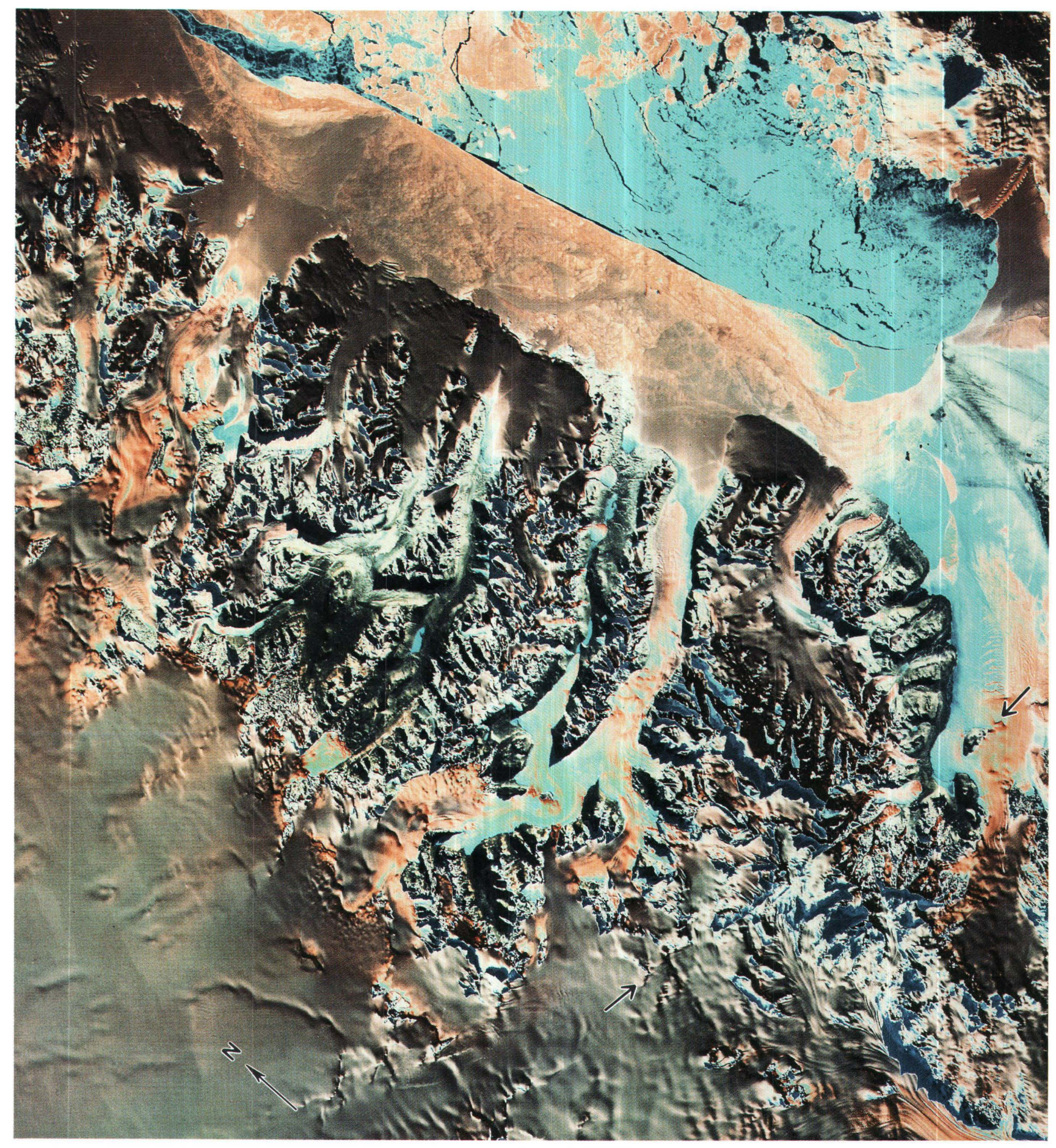

0

20 KILOMETERS

Figure 11. Sinusoidally stretched image of Mc Murdo Sound region and Dry Valleys. False-color multispectral composite of bands 4. 5, and 7 of Landsat 2 MSS image 2279-19361, 28 October 1975. In sinusoidal stretching, DN (digital number) values of dark and light areas were separately stretched over entire gray scale (Chavez a nd others, 1977). Light areas of original image (snow and ice scenes) are stretched in an inverse direction, giving a negative rendition. This method preserves maximum detail in both or iginal light and dark areas, but colors are unrealistic. Note conspicuous lineation between arrows, probably reflecting a structure. Ross Island at top right, Mc Murdo Station at tip of fingerlike peninsula extending southwestward from Ross Island. Dry Valleys are in center of image; within them, Lake Vanda shows as brilliant blue. Snow is brown, ice is greenish blue, and shadows are black or dark blue. 


\section{REFERENCES CITED}

Armstrong, Terrence, Roberts, Brian, and Swithinbank, Charles, 1973, Illustrated glossary of snow and ice: Cambridge, England, Scott Polar Research Institute, $60 \mathrm{p}$.

Arvidson, R.E., and Guinness, E.A., 1981, Integration of remote sensing, geophysical, and geological data sets to better understand the structural geology of the St. Francois Mountains, southeast Missouri and surrounding areas, in Carver, R.R., ed., 1981, International geoscience and remote sensing symposium digest: New York, Institute of Electrical and Electronic Engineers, p. 895896.

Behrendt, J.C., 1983, Are there petroleum resources in Ant arctica?, in Behrendt, J.C., ed., Petroleum and mineral resources of Antarctica: U.S. Geological Survey Circular 909, p. 3-24.

Bentley, C.R., and Giovinetto, M.B., 1962, Ice-flow studies on the ice dome of Roosevelt Island, Ant arctica: Transactions, American Geophysical Union, v. 43, no. 3, p. 369-372.

Brecher, H.H., 1982, Photogrammetric determination of surface velocities and elevations on Byrd Glacier: Antarctic Journal of the United States, v. 17 , no. 5, p. 79-81.

Budd, W.F., 1969, The dynamics of ice masses: Australian National Antarctic Research Expeditions, Scientific Reports, Series A (IV) (Glaciology), Publication No. 108, 216 p.

Bull, Colin, and Lipschutz, M.E., 1982, Workshop on Ant arctic glaciology and meteorites: Lunar and Planetary Institute Technical Report 82-03, 57 p.

Cassidy, W.A., 1979, Antarctic meteorites: Eos, Transactions, American Geophysical Union, v. 60, no. 13, p. 175-177.

Chavez, P.S., Jr., 1975, Atmospheric, solar and M.T.F. corrections for ERTS digital imagery[abs.], in American Society of Photogrammetry Symposium, Phoenix, 1975, Proceedings: Falls Church, Va., p. 69-69a.

Chavez, P.S., Jr., and Berlin, G.L., 1984, Digital processing of SPOT simulator and Landsat TM data for the SP Mountain region, Arizona, in SPOT Simulator Applications Handbook: $19 \overline{84}$ SPOT Symposium, Scottsdale, Ariz., May 20-23, 1984, Proceedings, p. 56-66.

Chavez, P.S., Jr., Berlin, G.L., and Mitchell, W.B., 1977, Computer enhancement techniques of Landsat MSS digital images for land use/land cover assessment, in Remote sensing of Earth resources, v. 6: Remote Sensing of Earth Resources, 6th Annual Conference, Tullahoma, Tenn., March 29-31, 1977, Proceedings of Technical Papers, p. 259-275.

Clapp, J.L., 1965, Summary and discussion of survey control for ice flow studies on Roosevelt Island, Antarctica: University of Wisconsin, Madison, Geophysical and Polar Research Center, Report 65-1, $98 \mathrm{p}$

Condit, C.D., and Chavez, P.S., Jr., 1979, Basic concepts of computerized digital image processing for geologists: U.S. Geological Survey Bulletin 1462, 16 p.
Cutts, J.A., and Blasius, K.R., 1981, Origin of Martian out flow channels--The eolian hypothesis: Journal of Geophysical Research, v. 863, no. 6, p. 50755102.

Dowdeswell, J.A., and McIntyre, N.F., 1986, The saturation of Landsat MSS detectors over large ice masses: International Journal of Remote Sensing, v. 7, no. 1, p. 151-164.

Drewry, D.J., Jordan, S.R., Jankowski, E., 1982 , Measured properties of the Antarctic ice sheet-Surface configuration, ice thickness, volume and bedrock characteristics: Annals of Glaciology, v. 3, p. 83-91.

Ferrigno, J.G., and Williams, R.S., Jr., 1983, Limitation in the use of Landsat images for mapping and other purposes in snow- and icecovered regions: Antarctica, Iceland and Cape Cod, Massachusetts, in International Symposium on Remote Sensing of Environment, 17th, Proceedings: Ann Arbor, Environmental Research Institute of Michigan, v. 1, p. 335-355.

Ferrigno, J.G., Williams, R.S., Jr., Southworth, C.S., and Meunier, T.K., 1983, Glaciological and geological studies of Antarctica with satellite remote sensing technology [abs.], in U.S. Geological Survey Polar Research Symposium-Abstracts with Program, Washington, D.C., Oct. 12-14, 1983: U.S. Geological Survey Circular 911, p. 20-21.

Hoffman, I.S., Keyes, Dale, and Titus, J.G., 1983, Projecting future sea level rise. Methodology, estimates to the year 2100 , and research needs-A report of the Strategic Studies Staff, Of fice of Policy Analysis, Office of Policy and Resource Management, U.S. Environmental Protection Agency: Washington, D.C., 2nd revised edition, $121 \mathrm{p}$.

Hughes, T.J., 1973, Is the West Antarctic ice sheet disintegrating?: Journal of Geophysical Research, v. 78, no. 33, p. 7884-7910.

1977, West Antarctic ice streams: Reviews of Geophysics and Space Physics, v. 15, no. 1, p. 146.

1981, The weak underbelly of the West Antarctic ice sheet: Journal of Glaciology, v. 27, no. 97, p. 518-525.

1983, On the disintegration of ice shelves--The role of fracture: Journal of Glaciology, v. 29, no. 101, p. 98-117.

Hughes, T.J., and Fastook, J.L., 1981, Byrd Glacier-1978-1979 field results: Antarctic Journal of the United States, v. 16, no. 5, p. 86-89.

MacDonald, W.R., 1976a, Antarctic cartography, in Williams, R.S., Jr., and Carter, W.D., eds., ERTS-1, a new window in our planet: U.S. Geological Survey Professional Paper 929, p. 3743.

1976b, Glaciology in Antarctica, in Williams, R.S., Jr., and Carter, W.D., eds., ERTS-1, a new window in our planet: U.S. Geological Survey Professional Paper 929, p. 194-195.

Marsh, P.D., 1985, Ice surface and bedrock topography in Coats Land and part of Dronning Maud Land, Antarctica, from satellite imagery: British Antarctic Survey Bulletin, no. 68, p. 19-36. 
Martin, P.J., 1976, Ridges on Antarctic ice rises: Journal of Glaciology, v. 17, no. 75, p. 141-144.

Martin, P.J., and Sanderson, T.J.O., 1980, Morphology and dynamics of ice rises: Journal of Glaciology, v. 25 , no. 91, p. 33-45.

Marvin, U.B., 1982, Meteorite placer deposits of Antarctica: Episodes, v. 1982, no. 3, p. 10-15.

Meunier, T.K., 1983, The use of satellite technology in the search for meteorites in Antarctica [abs.], in U.S. Geological Survey Polar Research Symposium--Abstracts with Program, Washington, D.C., Oct. 12-14, 1983: U.S. Geological Survey Circular 911, p. 19-20.

National Science Foundation, 1981, Antarctic meteorites provide new data: Antarctic Journal of the United States, v. 16, no. 2, p. 1-4.

Nye, J.F., 1959, The motion of ice sheets and glaciers: Journal of Glaciology, v. 3, no. 26, p. 493-507.

Ødegaard, Helge, and Helle, S.G., 1982, Polar mapping using Landsat data--Svalbard and Dronning Maud Land: Oslo, Norway, International Business Machines and Norsk Polarinstitutt, Final Report, $66 \mathrm{p}$.

Olsen, E.J., 1981, Estimates of total quantity of meteorites in the east Antarctica ice cap: Nature, v. 292, no. 5823, p. 516-518.

Orheim, Olav, 1978, Glaciological studies by Landsat imagery of perimeter of Dronning Maud Land, Ant arctica: Oslo, Norway, Norsk Polarinstitutt, Skrifter, no. 169, p. 69-80.

Paterson, W.S.B., 1981, The physics of glaciers (2d ed.): Oxford, Pergainon Press, 380 p.

Rivereau, J.C., 1978, Morphostructural outline of the Antarctic: Inventory of lineaments and outcropping areas from Landsat 1 and 2 imagery: Rueil-Malmaison, Bureau d'Etudes Industrielles et de Coopération de l'Institute Francais du Petrole (BEICIP).

Southard, R.B., and MacDonald, W.R., 1974, The cartographic and scientific application of ERTS1 imagery in polar regions: U.S. Geological Survey Journal of Research, v. 2 , no. 4, p. 385394.

Stephenson, S.N., and Doake, C.S.M., 1982, Dynamic behaviour of Rutford Ice Stream: Annals of Glaciology, v. 3, p. 295-299.

Stuiver, Minzo, Denton, G.H., Hughes, T.J., and Fastook, J.L., 1981, History of the marine ice sheet in West Antarctica during the last glaciation: A working hypothesis, in Denton,
G.H., and Hughes, T.J., eds., The last great ice sheets: New York, John Wiley and Sons, p. 319-436.

Swithinbank, C.W.M., 1963, Ice movement of valley glaciers flowing into Ross Ice Shelf, Antarctica: Science, v. 141 , no. 3579, p. 523-524.

Swithinbank, C.W.M., and Lucchitta, B.K., 1986, Multispectral digital-image mapping of Antarctic ice features: Annals of Glaciology, v. 8, p. 159163.

Trautwein, C.M., contributing author, 1983, Combined data sets: Geological applications, chapter 3 in Colwell, R.N., ed., Manual of remote sensing (2d ed.): Falls Church, Va., American Society of Photogrammetry, v. 2, p. 1757-1762.

Weertman, Johannes, 1974, Stability of the junction of an ice sheet and an ice shelf: Journal of Glaciology, v. 13, no. 67, p. 3-11.

Whillans, I.M., and Cassidy, W.A., 1982, Glaciologic notes on the Allan Hills area [abs.], in Bull, Colin, and Lipschutz, M.E., Workshop on Antarctic glaciology and meteorites: Lunar and Planetary Institute Technical Report 82-03, p. 51.

1983, Catch a falling star--meteorites and old ice: Science, v. 222, no. 4619, p. 55-57.

Williams, R.S., Jr., 1985, Monitoring the area and volume of ice caps and ice sheets: Present and future opportunites using satellite remotesensing technology, in Committee on Glaciology, Polar Research Board, Glaciers, ice sheets, and sea level--Effects of a $\mathrm{CO}_{2}$-induced climate change: Washington, D.C., National Academy Press, p. 232-240.

Williams, R.S., Jr., Ferrigno, J.G., and Kent, T.M., 1984, Index map and table of optimum Landsat 1, 2 , and 3 images of Antarctica: U.S. Geological Survey Open-file Report 84-573, 2 sheets (1:5,000,000-scale map).

Williams, R.S., Jr., Ferrigno, J.G., Kent, T.M., and Schoonmaker, J.R., Jr., 1982, Landsat images and mosaics of Antarctica for mapping and glaciological studies: Annals of Glaciology, v. 3, p. 321-326.

Williams, R.S., Jr., Meunier, T.K., and Ferrigno, J.G., 1983, Blue ice, meteorites, and satellite imagery in Ant arctica: The Polar Record, v. 21, no. 134, p. 493-496.

Znachko-Yavorskiy, G.A., 1978, The topography of Ant arctica: Polar Geography, v. 2, no. 1, p. 1-13. 


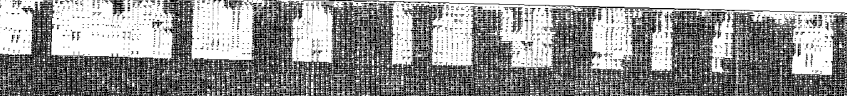
17 